\title{
Development of Integrated Thematic Teaching Materials using Problem-Based Learning Model in Elementary School
}

\author{
Risda Amini \\ Department of Primary Education \\ Universitas Negeri Padang, Indonesia \\ risdamini@fip.unp.ac.id \\ Yanti Fitria \\ Department of Primary Education \\ Universitas Negeri Padang, Indonesia \\ yanti_fitria@fip.unp.ac.id
}

\author{
Sry Eka Handayani \\ Department of Primary Education \\ Universitas Negeri Padang, Indonesia \\ sryekahandayani@gmail.com \\ Sri May Lena \\ Department of Primary Education \\ Universitas Negeri Padang, Indonesia \\ maisrilena111@gmail.com
}

\author{
Yullys Helsa \\ Department of Primary Education \\ Universitas Negeri Padang, Indonesia \\ elsa_khamek@yahoo.co.id
}

\begin{abstract}
This reseach is aimed to develop an integrated thematic teaching using problem-based learning model is valid, practical, effective in fourth grade elementary school. The research and development design used 4-D model which consists of 4 phases: the definition phase, design, development, and disseminate. Phase disseminate done on limited scale. In this research, six experts and three practitioners involved to validate the product. The data of the practicality were obtained from questionnaire distributed to the teachers and students and also from interview. The data of the effectiveness were seen from the students learning activities and their learning achievement as well that the covers attitude, knowledge, and skill aspects. The result of validity test indicated that the learning materials developed were very valid in which their average score was 3.89 (97.25\%), and the practicality test revealed that the analysis materialize lesson plan were practical in which the average score was $3.72(93 \%)$, and learning materials were very practical in which the average score gotten form the questionnaire responses given to the teachers was $87,50 \%$ and those given to the students was $91.7 \%$. The result of the effectiveness test showed that the average score of the students learning activities was $86,78 \%$. the students learning achievement on attitude aspect was $81,52 \%$, on knowledge aspects was $90,73 \%$, and on skill aspect was $81,70 \%$. Based on these results, it was conclude that development of integrated thematic teaching material using model problem-based learning in elementary school is valid, practical, effective.
\end{abstract}

Keywords: integrated thematic, teaching materials, problem-based learning model

\section{INTRODUCTION}

Education is a conscious and planned effort that functions to create a learning process atmosphere and develop students' potential such as religious spiritual strength, self-control, intelligence, good personality, and skills needed for themselves and society. It plays a very important role in ensuring the survival of the nation and state because education is the most appropriate means to improve and develop the quality of human resources. Moreover, the objectives of education according to the National Education System Law No. 20 year 2003 are to develop students' capabilities, shape dignified national character and civilization in order to educate the nation, develop the potential of students to become believers, have a good physical and spiritual, be competent, be creative, be independent, be a democratic, and be responsible citizen. In order to actualize these objectives, the government tries to improve the quality and management of education by carrying out various efforts such as improving the curriculum, facilities and infrastructure, quality of human resources, and increasing budget as well.

The government through the National Education Standards Agency (BSNP) has developed the 2013 Curriculum as an improvement for the previous curriculum. It is stated in Act of Ministry of Education and Culture Number 57 year 2014 that the basic framework of the elementary school curriculum is implementing the 2013 Curriculum that carried out through learning with integrated-thematic approaches from 1 st grade to 4 th". The integrated thematic learning is a learning that combines material from various fields of study. This method has developed since the children development is considered to be holistic, hence it will be more difficult for students if the learning process is conducted separately. Therefore, Ministry of National Education (Trianto, 2010: 79) states that "The term thematic learning is basically an integrated learning model that uses themes to associate several learning models in order to provide a meaningful experience for the students." Majid (2014: 122) states that "The 
integrated thematic learning is a learning approach that integrates various competencies and subjects into various themes'. Next, Ministry of Education and Culture (2014: 27) states that "The integrated learning uses themes as a unifying learning activity that combines subjects at once in order to provide a meaningful learning experience for the students. The students are always directed through direct learning experience and connected with other concepts that they mastered to make them understand the concept. Moreover, it shows that the integrated thematic learning is an appropriate method in order to combine learning activities and various subjects that can provide meaningful experiences to the students.

Since the curriculum has a major role in education, it is better to develop and socialize the curriculum in detail. Thus, the development of the 2013 curriculum needs various strong foundations in order to be used as a basis in conducting the educational process. The implementation of the 2013 curriculum has provided the teachers' and students' books which are used as teaching materials. The Ministry of Education and Culture Law No. 100 Year 2014 Article 1 states that "the students' and teachers' books are lesson texts and teacher manuals that set by the Minister of Education and Culture." Every school should be able to design and prepare the learning process carefully and always pay attention to each student. In sum, the preparation of the learning process is designed inseparable from the learning tools used in each learning process. One of the learning devices is a teaching material that can be used in each learning processes.

Further, the teaching or learning materials which are used by teachers and students in the learning process at school should systematically be arranged. Prastowo (2013: 36) states that "teaching material is a material that arranged systematically in order to create an environment or condition that makes students easily to learn". The teaching materials can be used as a guide for teachers to deliver the content of the specified subject. On the other hand, it can be used as a guideline that directs all activities in the learning process. If teaching materials are not in accordance with the criteria, various problems will arise in the learning process. In conclusion, one aspect that should be considered in the development of teaching materials is the conformity of the teaching material to the curriculum demands. It should be appropriate to the characteristics and social environment of students.

In some extent, subjects related to the theme in a learning process have been determined according to the teacher's reference book in the 2013 curriculum. As the matter of fact, the development of teaching materials is one of the main things that cannot be separated from the learning process. Therefore, the readiness of teaching materials is one of the factors for the success or failure of the thematic learning process given to elementary school students. Consequently, the teachers are expected to be more creative when developing teaching materials to facilitate students in learning process and should be based on scientific approach. On this sense, the integrated thematic learning in the 2013 curriculum has three learning models suggested by The Ministry of Education and Culture (2013: 11); Problem Based Learning (PBL), Project Based Learning (PjBL) and Discovery Learning (DL). The use of learning models is very helpful for teachers in delivering learning messages. With the learning model, they can easily manage the learning steps that will be applied to the students. Therefore, their role is important on designing and developing learning teaching materials in accordance with learning models that optimally support the learning process.

Conversely, based on the learning process observation and interview with the fourth-grade teachers at SDN Percobaan Padang on May 9, 2015, we found that many school teachers who used the 2013 curriculum assumed that the teacher's and student's book were the only references in the learning process. They did not analyse the curriculum before making the material. They did not use a companion and had not developed teaching materials too. They also did not persuade the students when the students faced the real problems. These limitations made the learning material to be less meaningful. Sometimes, the student did not get an explanation and did not learn how to solve problem. Moreover, they did not use the recommended learning model from the government in daily activities

Additionally, the researcher also analysed the teacher books and student books used in the schools. It was indicated that the book has not been updated gradually. It was found that there were limitations of theme 3 and sub-theme 3 on the teacher book, such as (1) the pair of the Basic Competencies did not match to each others, (2) 2 Basic Competencies used only 1 indicator, (3) learning objectives did not use KI 2 aspect or the required scope, (4) the development of indicators was not in accordance with the developed Basic Competencies, (5) no number for indicators, (6) the development of learning objectives was not in accordance with the indicators, and (7) the development of learning objectives did not encourage the students in group discussions. Moreover, there were also some limitations of theme 3 and sub-theme 3 on the student book; (1) the learning steps were interrupted and there was no relationship between the previous page with the next page, (2) the figures were lacking on information that should be easily understood by students, (3) lack on the students' activities to discuss learning process, (4) lots of learning materials that make students think about the continuation of the material, (5) lack on accuracy in the use of terms between reading and questions.

The problems above cannot be separated from the contribution of a teaching material. Then, the main problem is the inappropriate current practice of learning process with teaching materials. This problem gives an impact on the achievement of learning objectives as it should be. In addition, the development of teaching materials is needed to overcome these problems by considering appropriate learning models so that the expected goals will be achieved. Thus, the most suitable for developing teaching materials is by using problembased learning (PBL) model. It is a learning model that uses problems as the first step in collecting and integrating new knowledge. This problem is used to combine curiosity and the ability of students to think critically and analytically so they can find and use appropriate learning resources (Amir, 2009).

Problem-based learning basically emphasizes the importance of building students' own knowledge through 
active involvement in the learning process. Most of the time, the learning process takes place based on student activities. PBL has characteristics of learning that begin with giving problems related to the real world context. The students individually or in groups actively formulate problems and identify knowledge gaps they learn and search for material related to the problem. On the other side, the educators tend to be a facilitator (Amir, 2009: 12).

The writer chooses the problem-based learning (PBL) model in the development of teaching materials because it begins with the introduction of problems that can focus on the students' interest in the beginning of learning. If students are already focused on the learning, they will try to find and solve the prepared problem. The materials taught with the PBL model can also provide experiences for students to solve problems and find their own concepts. At the last activity, they will get feedback on their efforts to solve the problem, then they will get the concept. In summary, based on the previous explanations, the writer intends to propose this research as "The Development of Integrated Thematic Teaching Materials Using the Problem Based Learning Model in Elementary School Grade IV".

\section{METHOD}

This study used a developmental research method by proposing a problem-based learning model. The teaching materials were developed using 4-D model; defining, designing, developing, and disseminating. The study was conducted on 23 students from SDN Percobaan Padang (pilot school) and 31 students from SDN 05 Padang Pasir grade 4th (disseminate school).

\section{RESULT AND DISCUSSION}

Result

The results on the development of integrated thematic teaching materials using the Problem-Based Learning model for Grade IV Elementary School with 4$\mathrm{D}$ development model, gained the results of research data as follows in Table 1.

\section{Discussion}

The products developed in this study were Integrated Thematic Teaching Materials using the Problem Based learning model for 4th grade elementary school students. The products were tested to 23 of IVA graders at SDN Percobaan Padang and disseminated to 31 of 4th grade students at SDN 05 Padang Pasir.

\section{The Validity of Teaching Materials and Syllabus}

The validation of teaching materials was conducted based on several aspects such as content feasibility, language aspects, display aspects, and graphic aspects. The overall validation results obtained an average value of $3.89(97.25 \%)$ with a very valid category.

The syllabus validation was done based on several aspects like the aspects of identity, selection of competences, formulation of indicators, selection of learning materials, learning activities approaches, learning models, selection of learning resources, and assessment. The results of the syllabus validation carried out by expert validators obtained an average value of $3.91(97.75 \%)$ with a very valid category.

Table 1. Problem-Based Learning model 4-D development model

\begin{tabular}{|c|c|c|}
\hline Aspect & Average (\%) & Criteria \\
\hline \multicolumn{3}{|c|}{ The Validity of Teaching Materials and Syllabus } \\
\hline a) The teaching materials validity & $3,89(97,25 \%)$ & Very Valid \\
\hline b) The Syllabus validity & $3,91(97,75 \%)$ & Very Valid \\
\hline \multicolumn{3}{|l|}{ The Practicality of Teaching Materials } \\
\hline $\begin{array}{l}\text { a) The implementation of syllabus } \\
\text { for integrated thematic teaching } \\
\text { materials using problem-based } \\
\text { learning model. }\end{array}$ & $3,72(93 \%)$ & Practical \\
\hline $\begin{array}{l}\text { b) The teacher's response to the } \\
\text { practicality of teaching materials. }\end{array}$ & $87,50 \%$ & Very practical \\
\hline $\begin{array}{l}\text { c) The students' responses to the } \\
\text { practicality of teaching materials. }\end{array}$ & $91,70 \%$ & Very practical \\
\hline $\begin{array}{l}\text { d) The observation on the use of } \\
\text { teaching materials }\end{array}$ & & Practical \\
\hline e) The interview & & Practical \\
\hline \multicolumn{3}{|c|}{ The Effectiveness of Teaching Materials (Development Phase) } \\
\hline a. Students' activity & $86,96 \%$ & Very Active \\
\hline \multicolumn{3}{|l|}{ b. Learning Outcomes: } \\
\hline 1. Attitude Aspect & $81,52 \%$ & Well-established \\
\hline 2. Knowledge Aspect & $90,73 \%$ & Very Good \\
\hline 3. Skills Aspect & $81,70 \%$ & Good \\
\hline \multicolumn{3}{|c|}{ Effectiveness of Teaching Materials (Deployment Phase) } \\
\hline \multicolumn{3}{|l|}{ c. Learning outcomes } \\
\hline 1. Attitude Aspect & $84,42 \%$ & Well-established \\
\hline 2. Knowledge Aspect & $92,02 \%$ & Very Good \\
\hline 3. Skills Aspect & $84,27 \$$ & Good \\
\hline
\end{tabular}

\section{The Practicality of Teaching Materials}

Implementation of syllabus on Integrated Thematic Teaching Materials using Problem-Based Learning Model, Based on the results of observations, the feasibility of the syllabus using integrated thematic teaching materials in the IVA class of SDN Percobaan Padang in the trials stage was in practical criteria with an average value of $3.72(93 \%)$. The results of the questionnaire analysis of the teacher's responses to integrated thematic teaching materials with PBL models were very suitable in their daily learning process which obtain an average of $87.50 \%$ with a practical category. The results of the questionnaire analysis of students' responses to the practicalities of the developed teaching materials showed that the students were interested in learning integrated thematic teaching materials using the PBL model with an average response rate of 91.70 in a very practical category. The results of observations and interviews with teachers and the students in the Pilot School, SDN Percobaan Padang, showed that the developed teaching materials using Problem-Based Learning Model for class IV was practical to use.

\section{The Effectiveness of Teaching Materials (development stage)}

The results of the effectiveness test at the development stage showed that the activities of students in the IVA class at SDN Percobaan Padang showed a percentage with an average of $86.78 \%$ with a very active category. From the data above, it can be concluded that the learning process using problem-based learning model 
teaching materials was effective in the very active category (Pursitasari, 2015).

The attitude aspect of learning outcomes assessment on teaching materials using the PBL model in grade IV SDN Percobaan Padang showed an average percentage of $84.42 \%$ with with a well-established category. The knowledge aspect of learning outcomes assessment on teaching materials using the PBL models in grade IV SDN Percobaan Padang showed an average percentage of $90.73 \%$ with a very good category. The skills aspect of learning outcomes assessment on teaching materials using the PBL model in grade IV SDN Percobaan Padang showed an average percentage of $81.70 \%$ with a good category.

\section{Effectiveness of Teaching Materials (distribution stage)}

The attitude aspect of learning outcomes assessment on teaching materials using the PBL model in grade IV SDN 05 Padang Pasir show an average percentage of $81.52 \%$ with a well-established category. The knowledge aspect of learning outcomes assessment on teaching materials using the PBL models in grade IV SDN 05 Padang Pasir showed an average percentage of $92.02 \%$ with a very good category. The skills aspect of learning outcomes assessment on teaching materials using the PBL model in grade IV SDN 05 Padang Pasir showed an average percentage of $84.27 \%$ with a good category.

\section{CONCLUSION}

There are some conclusions that can be drawn based on the result and discussion above; (1) The developed teaching materials using Problem-Based Learning Model in this research are very valid in the aspect of contents, language, display and graphics. Further, the syllabus used is also considered to be valid. (2) The developed teaching materials using Problem Based Learning Model in this research are stated to be very practical from the implementation of the lesson plan, teacher's response analysis, students' response analysis, observation of the use of teaching materials and interviews, and (3) The developed teaching materials using Problem-Based Learning Model in this research are effective measured from the activities and learning outcomes. The students' activities can be seen from the results of student observations at the pilot school and student learning outcomes that include 3 aspects; attitudes, knowledge, and skills at the pilot school and the disseminate school.

The integrated thematic teaching materials based on the PBL model are very effective to be used in the learning process. The development of these materials can be done by every teacher using practicality, validity, and the effectivity criteria in order to determine the quality of teaching materials. Thus, the teaching materials developed will be in accordance with the expected results and the right targets according to the actual educational objectives. Importantly, the teachers' creativity is indispensable in choosing and utilizing existing learning resources and adapted to the methods and strategies of school learning.

\section{REFERENCES}

[1] Amini, Risda dan Helsa Y. 2018. Integrated model in science for elementary school. Journal of physics vol 1088. No.1, p.012057; conferenceseries; iop.org

[2] Amini, Risda. 2017. Development of Integrated Learning based Students' Book to improve elementary school Students' http;//journal.unnes.ac.id/sju/index.php/ussej

[3] Amir, M.Taufik. 2013. Inovasi Pendidikan Melalui Problem Based Learning. Jakarta: Kencana

[4] Majid, A. (2014). Pembelajaran tematik terpadu. Bandung: PT Remaja Rosdakarya.

[5] Tiffa A. Putri, Zuardi, Risda Amini. 2018. Pengaruh Penggunaan Model Pembelajaran Problem Learning Terhadap Hasil Belajar IPS di SD. e-Journal Pembelajaran Inovasi vol 6 no 2

[6] Trianto. 2010. Model Pembelajaran Terpadu. Jakarta: Bumi Aksara.

[7] Jerrell C. C. 1990. Dampak dari Sistem Pembelajaran Terpadu Reading Berfokus pada Kesadaran Fonologis di TK. Journal Keaksaraan Penelitian vol 4. Ball State University

[8] Prastowo, A. (2013). Pengembangan bahan ajar tematik. Yogyakarta: Diva Press.

[9] Pursitasari, Indarini, Dwi Siti Nuryanti, Amran Rede. 2015 Promoting of Thematic-based Integrated Science Learning on the Junior High School. Journal of Education and Practice vol.6, no.20. www.iiste.org 